\title{
DHODH Gene
}

National Cancer Institute

\section{Source}

National Cancer Institute. DHODH Gene. NCI Thesaurus. Code C26537.

This gene plays a role in pyrimidine metabolism. 